\title{
Distribution Profile of Chemical Elements during the Last 13 Thousand Years from the Sediments of Maloye Yarovoe Lake (Western Siberia, Russia)
}

\author{
Marina Kolpakova ${ }^{1, *}$, Olga Gaskova ${ }^{1,2}$, Svetlana Borzenko ${ }^{3}$, Sergey Krivonogov ${ }^{1,2}$, \\ Olga Naymushina ${ }^{1}$ and Natalia Rudaya ${ }^{1,4,5}$ \\ 1 Sobolev Institute of Geology and Mineralogy, SB RAS, 630090 Novosibirsk, Russia; \\ gaskova@igm.nsc.ru (O.G.); s_krivonogov@mail.ru (S.K.); naymushinaos@igm.nsc.ru (O.N.); \\ nrudaya@gmail.com (N.R.) \\ 2 Novosibirsk State University, 630090 Novosibirsk, Russia \\ 3 Institute of Natural Resources, Ecology and Cryology, SB RAS, 672002 Chita, Russia; svb_64@mail.ru \\ 4 Institute of Archaeology \& Ethnography, SB RAS, 630090 Novosibirsk, Russia \\ 5 Biological Institute, Tomsk State University, 634000 Tomsk, Russia \\ * Correspondence: marina.kolpakova@gmail.com; Tel.: +46-76-938-3445
}

Received: 28 September 2020; Accepted: 22 October 2020; Published: 26 October 2020

\begin{abstract}
The article presents the studies on understanding the chemical evolution of Maloye Yarovoe lake that is located in the semi-arid landscape of and represent the most widespread chemical type of saline lake (Cl-Na) on the territory of Kulunda steppe (south of Western Siberia). The lake has gone through several changes in its state which are well represented in its sediments: section 1 $(4.52-4.97 \mathrm{~m})$ represents the subbase; section $2(3.0-4.57 \mathrm{~m})$ corresponds to a "shallow lake" stage and contains two sublayers; section $3(0-2.25 \mathrm{~m})$ illustrates an increase in erosion of the shoreline and corresponds to a "deep lake" stage. The extrapolation of radiocarbon dates suggests that the most significant changes in the state of the lake occurred at about 6.5-7.1 ka BP (transition from a small lake to a large one with intensified coastal erosion) and at about 5.69 and $3.5 \mathrm{ka}$ BP (increase in the organic component). The results of sequential extraction of elements correspond to chemical changes occurred in a certain time of the lake state by changing in their distribution level and fraction type along the core. The results of lake water evaporation and organic matter degradation modelling performed in Phreeqc for oxic and anoxic condition showed the following stages of chemical divides could be expected in case of further lakes desiccation: Halite-Epsomite-Bischofite/Carnalite with possibility of Nahcolite precipitation in carbonate enriched periods (summer and autumn periods of organic matter degradation). Water-rock interaction processes in combination with biogeochemical reactions affect drastically not only the migration features of elements in water and sediments, but also the type of mineral crystallization in lake sediments.
\end{abstract}

Keywords: lake sediments; saline lake; sequential extraction; water-rock interaction

\section{Introduction}

Recently, chemical evolution of surface and groundwaters have become one of the most serious questions due to ongoing climate change [1-3]. Being great representatives for understanding the regularity of chemical divide, saline lakes caught the particular attention in recent years [4-8]. However, the complexity of chemical processes in these complicate and multi-component systems [9] limits the possibilities of geochemical modelling for solutions with high ionic strength [10]. Moreover, actively occurring biogeochemical processes affect not only organic matter distribution, but also geo-cycles of such elements as carbon or sulfur [11-13], making the investigations even more complicate. 
In order to reconstruct detailed mechanisms of transformation of saline lake sediments (during the stage of early diagenesis) it is necessary to understand all the interaction processes between organic matter (OM) and inorganic chemical components. Diagenesis is a combination of physical-chemical and biological processes which take place in an "open" system that initially is chemically not in an equilibrium state due to constant water renewal and that is enriched in organic matter, both living bacteria and decomposed organic (organic acids, etc.). At the final stage of diagenesis, as a result of long redistribution, sediments of saline lakes can be considered even as ore deposits for $\mathrm{U}, \mathrm{Mn}, \mathrm{Pb}$, $\mathrm{Cu}$, etc [14].

Water-sediment interface at the bottom of saline lakes is characterized by a significant mass transfer of dissolved particles, particulate matters, and burial of elements in the sedimentary sequence. Watershed areas supply these materials to continental lakes through the discharge of groundwaters or rivers or during coastal and wind (Aeolian sediments) erosion. These processes are largely controlled by hydrological, biological, and chemical processes. Redox processes, precipitation-dissolution reactions, adsorption-desorption exchanges, and microbial reactions occur simultaneously here, causing the appearance of chemical and biological properties [15-18].

The early stage of diagenesis (eogenesis) in marine or saline environments such as continental or coastal lakes has been defined by K. Hummel in 1922 [19] (p. 116) as "halmyrolysis" (halmyros = salty; lysein = to dissolve). He considered it as a complex of "all chemical and physicochemical processes which occur during the water transportation, weathering and the pre-burial stage of diagenesis". Early diagenetic changes lead not only to the physical transformations of bottom sediments (decrease in humidity and porosity, the formation of concretions), but also to changes in the amount and composition of organic substances that affects the intensity of oxidation and precipitation processes and also to changes in the migration/precipitation species of elements and their redistribution along the depth of sediments (the pre-burial stage of diagenesis according to K. Hummel [19]). Thus, in-situ formation of secondary clay minerals (kaolinite, k-feldspars, montmorillonite), precipitation of salts and minerals (in aerobic and reducing conditions) and organic matter (OM) degradation are the main processes studied in current article.

Modern studies of diagenetic processes in Russia are focused mainly on the large objects such as Karelian lakes [20,21] or Lake Baikal [22]. Small continental reservoirs, such as salt lakes, have received attention in [23-26] to interpret the ancient and modern history of a saline lake. By this work, we open a series of articles devoted to a study of saline ecosystems of semi-arid region of the south of Western Siberia. The present study is focused on understanding the chemical evolution of Maloye Yarovoe saline lake and processes caused the changes in chemical composition of its water and sediments.

\section{Materials and Methods}

\subsection{Studied Area}

The endorheic Maloye (in some transcriptions Maloe) Yarovoe lake ( $53^{\circ} 04^{\prime} \mathrm{N}, 79^{\circ} 05^{\prime} \mathrm{E}, 95$ m.a.s.l.) is located in the Kulunda depression on a territory of Western Siberia (Russia). This territory is distinguished by high variety of saline lakes of diverse chemical composition [27-29]. The lake has the area of $35 \mathrm{~km}^{2}$ and the maximum depth of $5 \mathrm{~m}$ (Figure 1) with steep banks and Scirpus hippolytii Krecz. and S. tabernaemontani C.C. Gmel. [30] behind the cliffs. The mud of the lake is used for medicinal purposes by the Znamenskaya Hospital opened in 1991. The lake is highly popular for camping tourism during summer period (50-100 people daily in June-August). 


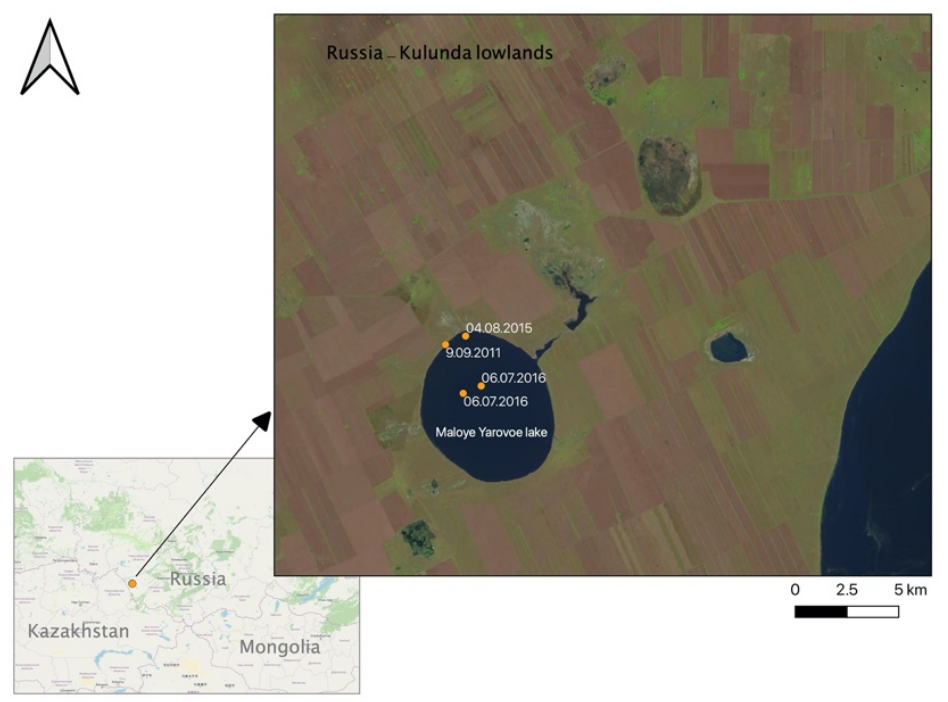

Figure 1. The location of Maloye Yarovoe lake (Kulunda lowland, Russia) with samples locations (data sources: Landsat-8 satellite image from EarthExplorer.usgs.gov with QGIS OSM Standard base map).

Geologically, the basement of Kulunda steppe basin is formed during Cenozoic era of alluvial and lake-alluvial relief and is made up of sandy-clayey composition lenses of gypsum and carbonates. Chemical composition of groundwaters is heterogeneous and can vary from HCO3-Ca $(\mathrm{Na})$ to $\mathrm{SO}_{4}-\mathrm{Ca}-\mathrm{Mg}(\mathrm{Na})$ and $\mathrm{Cl}-\mathrm{Na}$. The annual groundwater flow on the territory is small $\left(0.2-0.4 \mathrm{~L} / \mathrm{s} \cdot \mathrm{m}^{2}\right)$ [31].

Most data about climate of Altai region are related to 60-70 years of last century [31,32], according to which the duration of warm period with stable positive temperature in Altai region is on average 190-200 days (starting on 10-15 April and ending on 23-27 October). Water temperature during summer period varies from 18 to $24{ }^{\circ} \mathrm{C}$; the period with temperature below $-15^{\circ} \mathrm{C}$ is $80-85$ days; "ice-on" period for the lakes is approximately the same. However, recent study of agro-dynamic changes [33] showed that climate change causes significant increase in temperature and precipitation level. According to the data of Russian Federal Service for Hydrometeorology and Environmental Monitoring [34], the average speed of temperature rise in Russia is $0.47^{\circ} \mathrm{C} / 10$ years with the highest rise during spring $\left(0.61{ }^{\circ} \mathrm{C} / 10\right.$ years). The southern part of Western Siberia region where the lake is located, however, has the minimal value of temperature increase $\left(0.2-0.3^{\circ} \mathrm{C} / 10\right.$ years). The amount of precipitates, at the same time, increases to $5 \%$ for the last 10 years, with the largest increase is in spring.

\subsection{Water Sampling and Analysis Methods}

The studying was carried out in July-August period during summer time of 2011, 2015 and 2016 years (Table S1). Water samples were taken from the depth of $30-40 \mathrm{~cm}$, filtered through 0.45 and $0.2 \mu \mathrm{m}$ membrane filters and collected in $0.5 \mathrm{~L}$ plastic bottles for analysis of major components and in $250 \mathrm{~mL}$ polypropylene bottles for analysis of trace elements.

Pore-waters from the core were collected by squeezing at a pressure of 100-120 bar. The obtained solution was collected in sterile containers and immediately sent to a chemical laboratory for subsequent analysis.

Chemical-analytical measurements of water samples were carried out according to generally accepted methods using mass spectral methods, as well as atomic absorption, flame emission, potentiometry, titration, etc. More details can be found in [35].

\subsection{Sediments Sampling and Analysis Methods}

The lake sediments were drilled in the central part of the lake $\left(53^{\circ} 5^{\prime} \mathrm{N}, 79^{\circ} 7^{\prime} \mathrm{E}\right)$ at the depth of $3.6 \mathrm{~m}$ from inflatable pontoon using a Livingston-type sampler $2 \mathrm{~m}$ long and $7 \mathrm{~cm}$ in diameter. The retrieved core comprises of three undisturbed lots of the sediments, totally $497 \mathrm{~cm}$ long. The core 
was hermetically packed on the drilling site and opened, described and subsampled in the lab. However, the $\mathrm{pH}$ and Eh measures were performed on site.

Standard sedimentological analysis has been performed at the $5 \mathrm{~cm}$ sampling interval and included determination of proportions of main sediment components by their sequential removal: water soluble salts (chlorides and mirabilite), 30\% hydrogen peroxide (organic matter), 10\% chlorine acid soluble salts (mostly carbonates), and the retained insoluble part, which consisted of terrigenous minerals and gypsum (in the lower half of the core). Proportions of the latter were estimated visually.

To estimation the age of sediments, two sets of dates were obtained at the Novosibirsk Centre for Collective Use 'Geochronology of Cenozoic' of the Siberian Branch of Russian Academy of Science and the National Taiwan University (NTUAMS) from samples of sediment organic matter (TOC) by AMS method. The detailed description of calibration and modelling age data technics can be found in [36].

To study the morphology and composition of individual grains using an electron scanning microscope, the most interesting grains were selected from samples of bottom sediments and glued to carbon tape. The prepared samples were viewed on a TESCAN MIRA3 LMU scanning electron microscope (TESCAN, Brno, Czech Republic) with an Inca-Energy dispersive attachment for quantitative analysis (laboratory of X-ray spectral analysis of the IGM SB RAS, Oxford Instruments, Moscow, Russia). The crystals photographs were taken at the Center for Collective Use of the Institute of Cytology and Genetics SB RAS using a Stemi 2000 CS microscope with an AxioCam HRc digital camera (Carl Zeiss LLC, Novosibirsk, Russia).

The dried bottom sediments were homogenized. Mineralogical composition was determined using X-ray spectral analyses in the IGM SB RAS. The XRD measurements were carried out on a DRON-4 automated powder diffractometer ( $\mathrm{CuK}_{\alpha}$ radiation, graphite monochromator). The diffraction patterns were scanned in the interval $2 \theta$ from $3^{\circ}$ to $65^{\circ}$ in increments of $0.05^{\circ}$; the scan time at the point was $4 \mathrm{~s}$, and the slit was $0.5 \mathrm{~mm}$. Elemental composition was analyzed via X-ray fluorescent element analysis at the Siberian Synchrotron and Terahertz Radiation Centre (INP SB RAS). For quality control, the IAEA/SOIL-7 standard (Laboratory Seibersdorf, Vienna, Austria) was included with each batch of digestion. Quantitative X-ray fluorescence analysis of silicates was performed from fusion tablets: the analyzed sample was dried at $105^{\circ} \mathrm{C}$ for $1.5 \mathrm{~h}$, then calcined at $960{ }^{\circ} \mathrm{C}$ for $2.5 \mathrm{~h}$ and then mixed with flux (66.67\% lithium tetraborate; $32.83 \%$ lithium metaborate and $0.5 \%$ lithium bromide) in a ratio of 1:9 (the total weight of the mixture is $5 \mathrm{~g}$ ). The mixture was melted in platinum crucibles in a Lifumat-2,0-Ox induction furnace. Measurements were performed on an ARL-9900XP X-ray fluorescence spectrometer ARL-9900XP (Thermo Fisher Scientific Ltd., Hong Kong, China). Loss on ignition (LOI) was considered to be an indirect index for total carbon [37].

To study chemical fractionation of elements, the updated sequential extraction technique of Tessier [38] was performed [39] on $4 \mathrm{~g}$ (wet wt.) of homogenized sediments in seven stages (Table S1): water-soluble, exchangeable, carbonate, organic (humic), reducible, oxidizable, and residual (acid decomposition). Since the initial salinity of sediments was high, the first stage was performed in three identical consecutive steps to ensure complete removal of water-soluble salts. After each stage of extraction, the residue material was rinsed with $10 \mathrm{~mL}$ of distilled water and centrifuged 5000-7000 rpm for $10 \mathrm{~min}$.

\subsection{Geochemical Modelling}

Since chemical reaction taking place in bottom sediment varies from those in lake-water, the modelling of evaporation processes was performed under two different conditions: oxic and reducing condition.

The latest studies [40] indicated the significant role of saline lakes in global $\mathrm{C}$ cycling due to their high $\mathrm{CO}_{2}$ emission (0.28-0.32 gigatonnes (Gt) $\mathrm{CO}_{2}$ annually). The average areal $\mathrm{CO}_{2}$ exchange rate with the atmosphere of saline lake was about sixfold greater than that reported for freshwater lakes. Moreover, the authors highlight that saline lakes with $\mathrm{pH}<9$ were generally higher net sources of $\mathrm{CO}_{2}$ 
to the atmosphere whereas lakes at or above $\mathrm{pH} 9$ were commonly weak $\mathrm{CO}_{2}$ sinks. Thus, the first part of calculations was made under oxic condition in equilibrium with partial pressure $\mathrm{pCO}_{2}=10^{-3.5} \mathrm{~atm}$.

The common feature of all evaporites is that they are composed of salts easily soluble in water [41]. Hardie and Eugster theory [42] of evaporitic sedimentation has been widely used to explain the changes in chemical composition of land surface-water objects such as saline lakes and playas. According to that theory, as water solution evaporates, it becomes sequentially supersaturated with newly formed secondary minerals of different composition, the formation of which leads to the transition of one chemical type to another $[43,44]$. The forming mineral assemblages though strongly depend on chemical composition of initial solution and ion ratios.

Saline lake is a unique environment where different processes occur in water and sediments. Oxygen-rich conditions of surface-water layer provide high variability of mineral assemblages and organic-rich and reduce environment of pore-water allows prosperity of early diagenetic processes such as sulfate reduction, carbon-enrichment due to decomposition of organic matter, redeposition of minerals.

The simulation of evaporation processes was performed by removing 1 mole of $\mathrm{H}_{2} \mathrm{O}$ at each step and continued until the complete withdrawal of 52-53 moles $\mathrm{H}_{2} \mathrm{O}$ (94-95\%). The modelling was carried out by using PHREEQC software (U.S. Geological Survey, USA, freely distributed) [45]. The databases used for simulations in oxic and anoxic environments (PITZER.dat and LLNL.dat, respectively) varied due to the limitation of PITZER database. LLNL.dat was chosen because of its extended data of thermodynamics for uranium and other trace elements with variable valency.

Redox environment of bottom sediments controls the behavior of variable-valency elements and is characterized by higher content of organic compounds. The modelling was performed with starting Eh value equals to $-200 \mathrm{mV}$ with the following adjustment of Eh was due to $\mathrm{S}(6) / \mathrm{S}(4)$ ratio. The degradation of organic matter was simulated by adding $0.007 \mathrm{~mol}$ of $\mathrm{CH}_{2} \mathrm{O}$ at each step, which is equal to the total amount of $10 \mathrm{mg} / \mathrm{L}$ of dissolved organic carbon (DOC) according to our measurements.

\section{Results}

\subsection{Lake Water Chemistry}

Maloe Yarovoe lake is of Cl-Na type with small amounts of $\mathrm{Mg}^{2+}(4-6$ eq.\%) and acts as a common representative of the Siberian steppe saline lakes $[25,46]$. The chemistry of lake water is characterized by relatively high salinity $220 \mathrm{~g} / \mathrm{L}$, neutral to base $\mathrm{pH}(7.75)$ and near-oxic (Eh is $45-60 \mathrm{mV}$ ) environment (Table S2).

Pore waters (Table S2) collected from the upper layer $(0-20 \mathrm{~cm})$ of sediments are quite similar to the lake waters except for slightly higher concentrations of $\mathrm{SO}_{4}{ }^{2-}$. Pore waters of deeper layer $(140-187 \mathrm{~cm})$ could not be studied on major anions composition due to the small amount of extracted water, however according to ICP-MS analysis, their cation composition is different. The contents of $\mathrm{Na}^{+}$and $\mathrm{Mg}^{2+}$ are significantly reduced, while calcium remains at its average value for the whole lake environment. The last is not surprising, giving that groundwaters of the region are saturated or even supersaturated with respect to Calcite limiting $\mathrm{Ca}^{2+}$ accumulation in solution.

Trace elements composition of water samples in the lake is quite stable (Table S3) and is correspond with the average values for saline lakes of Kulunda steppe (Kolpakova, 2019). Concentration of Mn and Mo changes after filtration that illustrates the possible organic $(0.2 \mu \mathrm{m})$ or colloid $(0.45 \mu \mathrm{m})$ bounding for these elements. Pore waters from the upper layer is characterized by higher values of $\mathrm{Sr}, \mathrm{Fe}, \mathrm{Cr}, \mathrm{Ca}$, $\mathrm{S}$ and lower for $\mathrm{Zn}, \mathrm{B}, \mathrm{Ba}$. Pore waters of the deeper layer differs vastly from lake water and upper layer. For example, $\mathrm{Al}$ and $\mathrm{Si}$ content is much higher (Figure 2). 




Figure 2. Trace elements composition of lake- and pore-water.

\subsection{Bottom Sediments}

The first $50 \mathrm{~cm}$ of the obtained sediments is a muddy substance of dark grey-black color. After $50 \mathrm{~cm}$ there is a smooth transition to the next layer of blue-grey clay with evaporite minerals that is distributed along the entire core either on the specific intervals (2.58-2.62, 3.17-3.22 m) or as salt crystals (Figure 3). After opening the core and access of oxygen, the crystals become quickly covered with white coating that can be indicated as a possible mirabilite dehydration. The smell of $\mathrm{H}_{2} \mathrm{~S}$ is noticeable along the entire core (especially at the intervals of 1.4-1.87, 2.0-2.4, 3.12-3.17 m). Physical-chemical conditions of the sediments are the opposite one to the lake water: The redox value is near $-374 \mathrm{mV}$, the $\mathrm{pH}$ values are in average 6.93 with a decrease in some intervals down to 6.76.
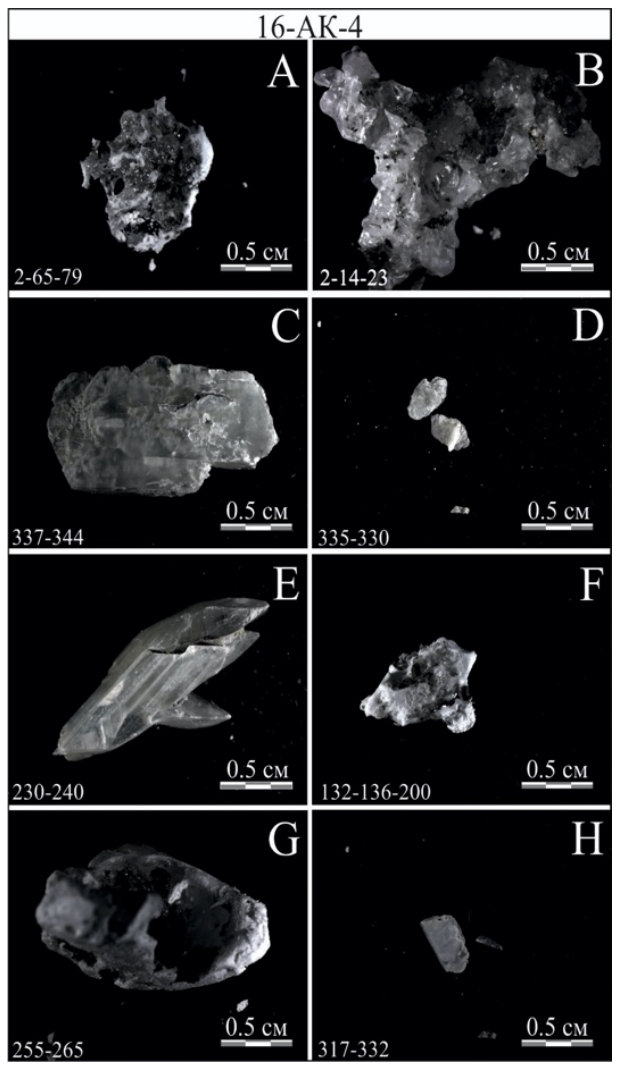

Figure 3. The photos of salt crystals found in sediments. 


\subsubsection{Radiocarbon Dating}

Both sets of dates for radiocarbon dating show linear trends in the accumulation of lake sediments, however the interval above the salt layer do not coincide and only 8 dates were used for age modelling [36].

The obtained dates suggest continuous sedimentation for the section above the salt layer, which lasted about $10 \mathrm{ka}$ BP (Figure 4). A $5 \mathrm{~cm}$ thick salt layer reflects $0.09 \mathrm{ka}$ BP long precipitation (10.10-10.19 ka BP). The extrapolation of dates below the salt layer suggests that the age of the lake subbase is $12.9 \mathrm{ka}$ BP. Other significant changes in the state of the lake occurred at about 6.5-7.1 ka BP at a depth of 225-250 cm (transition from a small lake to a large one with intensified coastal erosion), about 5.69 and $3.5 \mathrm{ka} \mathrm{BP}$ at depths of 190 and $100 \mathrm{~cm}$, respectively (increase in the organic component).



Figure 4. Schematic ${ }^{14} \mathrm{C}$-data indicating interruptive sedimentation and sediments visual description.

The numerical reconstruction of annual precipitation (mm/year) in the Holocene and Younger Dryas (YD) performed on the same sediments of Maloye Yarovoe [47] showed the rapid increase of annual precipitation from 285 in YD to $340 \mathrm{~mm} /$ year in Holocene. The transition period from "shallow lake" to "deep lake" stages (or between section 2 and section 3) $6.4 \mathrm{ka}$ BP was accompanied by even higher PANN (352 mm/year).

\subsubsection{Lithostratigraphy and Mineralogy}

According to the data of sedimentary stratigraphy (Table S4, Figure 5) and X-ray analysis (Table S5, Figure 6) there are three major sections with several subdivisions along the core.

The bottom-most, or subbase, section 1 (4.52-4.97 m, dating at $12.98 \mathrm{ka} \mathrm{BP})$ represents the underlying rocks and have an average mineral component of $65 \%$, organic $(20 \%)$ and salts of mainly carbonate composition (15\%, Table S4). Mineralogy is presented mainly by detrital components such as Quartz, Plagioclase and Chlorite; Halite and Calcite are also present with traces of Hematite (Table S5).

The upper part of the core is the lake sediments $(0-4.52 \mathrm{~m})$ is divided into two parts: section 2 with higher salinity and section 3 with lower salinity. Sedimentological analysis shows the predominance of terrigenous clay along the entire sediment. In the range of the section $2(4.52-2.25 \mathrm{~m} / 6.4-12.98 \mathrm{ka} \mathrm{BP})$, it is on average $37 \%$ and about $55 \%$ (with significant fluctuations) in section $3(0-2.25 \mathrm{~m} / 0-6.4 \mathrm{ka} \mathrm{BP}$ ). There are also different ratios of salts and organic matter (Table S4). The content of organic part varies 
from $24 \%$ (section 2) to $16 \%$ (section 3). Described changes in sedimentology are probably associated with varying degrees of shoreline erosion in sections 2 and 3 and suggest the presence of smaller and more saline pond at the beginning of lake evolution, and higher level of water on the latest stages.

Section 2 corresponds to a "shallow lake" stage and contains 2 sublayers. The lower section 2a (3.4-4.57 m/10.4-12.98 ka BP) is made up of mostly detrital terrigenous components ( 40\%) and enriched by carbonate minerals (16) and salts (10\%) such as halite. The organic compound varies strongly from 16 to $60 \%$ with $26 \%$ in average (Table S4), which is the highest value along the sediments. section 2 has a peak of salinity at section $2 \mathrm{~b}(3.0-3.4 \mathrm{~m} / 8.9-10.4 \mathrm{ka} \mathrm{BP})$ where the content of authigenic minerals increases sharply (in average is 50\%), reaching the highest 70\% in the salt layer $(3.27-3.32 \mathrm{~m} / \sim 10 \mathrm{ka} \mathrm{BP}$ ). Mineral assemblages are represented mostly by water-soluble salts such as gypsum $\left(\mathrm{CaSO}_{4} \cdot 2 \mathrm{H}_{2} \mathrm{O}\right)$ or anhydrite $\left(\mathrm{CaSO}_{4}\right.$, Figure $\left.7 \mathrm{a}\right)(43 \%)$, also halite $(\mathrm{NaCl})$ and calcite $\left(\mathrm{CaCO}_{3}\right)$. SEM X-ray analysis shows that the peak of salinity falls on 3.09-3.22 $\mathrm{m}(9.4-9.8 \mathrm{ka} \mathrm{BP})$ there thernadite $\left(\mathrm{Na}_{2} \mathrm{SO}_{4}\right)$ and hydroglauberite $\left(\mathrm{Na}_{2} \mathrm{SO}_{4} \cdot \mathrm{CaSO}_{4}\right)$ are detected (Figure 6). These minerals are quite common in evaporite formations of Kulunda steppe [28]. The photos of salt crystals found in sediments with prismatic (C, E, $\mathrm{H})$ and isometric $(B, G)$ habitus are presented in Figure 3. Some crystals (most likely mirabilite) melted during sample preparation forming a white coating on the surface of the crystals (thernadite). The salt layer, that is the maximum reduction in the lake, is characterized by an absolute minimum proportion of terrigenous substances ( 7\%). Section 2c (2.25-3.0 m/6.4-8.9 ka BP) is carbonate-rich $(14 \%)$ and has the lowest organic compound (21\%) in the whole section.

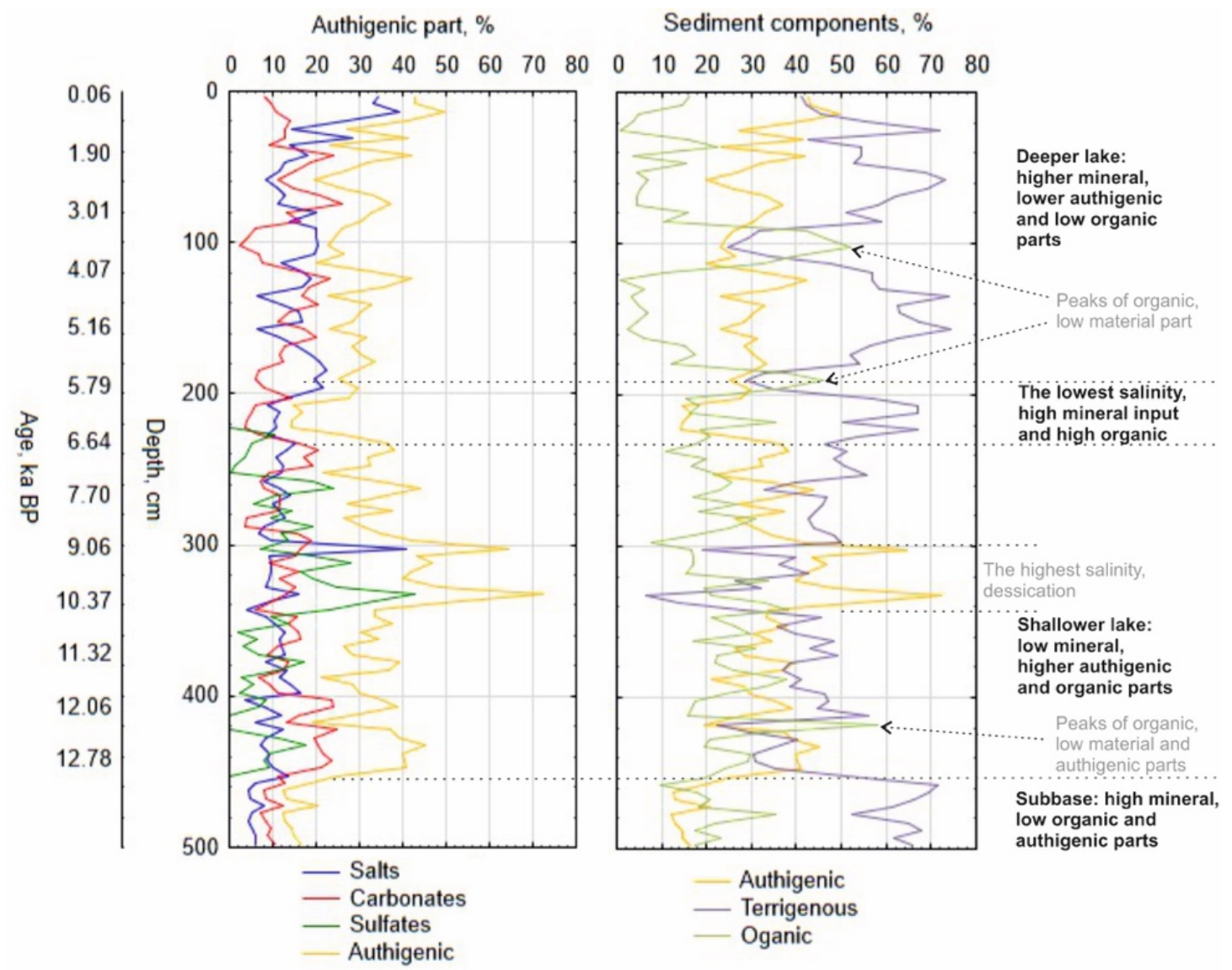

Figure 5. Changes of terrigenous, organic and authigenic fractions along the sediment core and their environmental interpretation. 

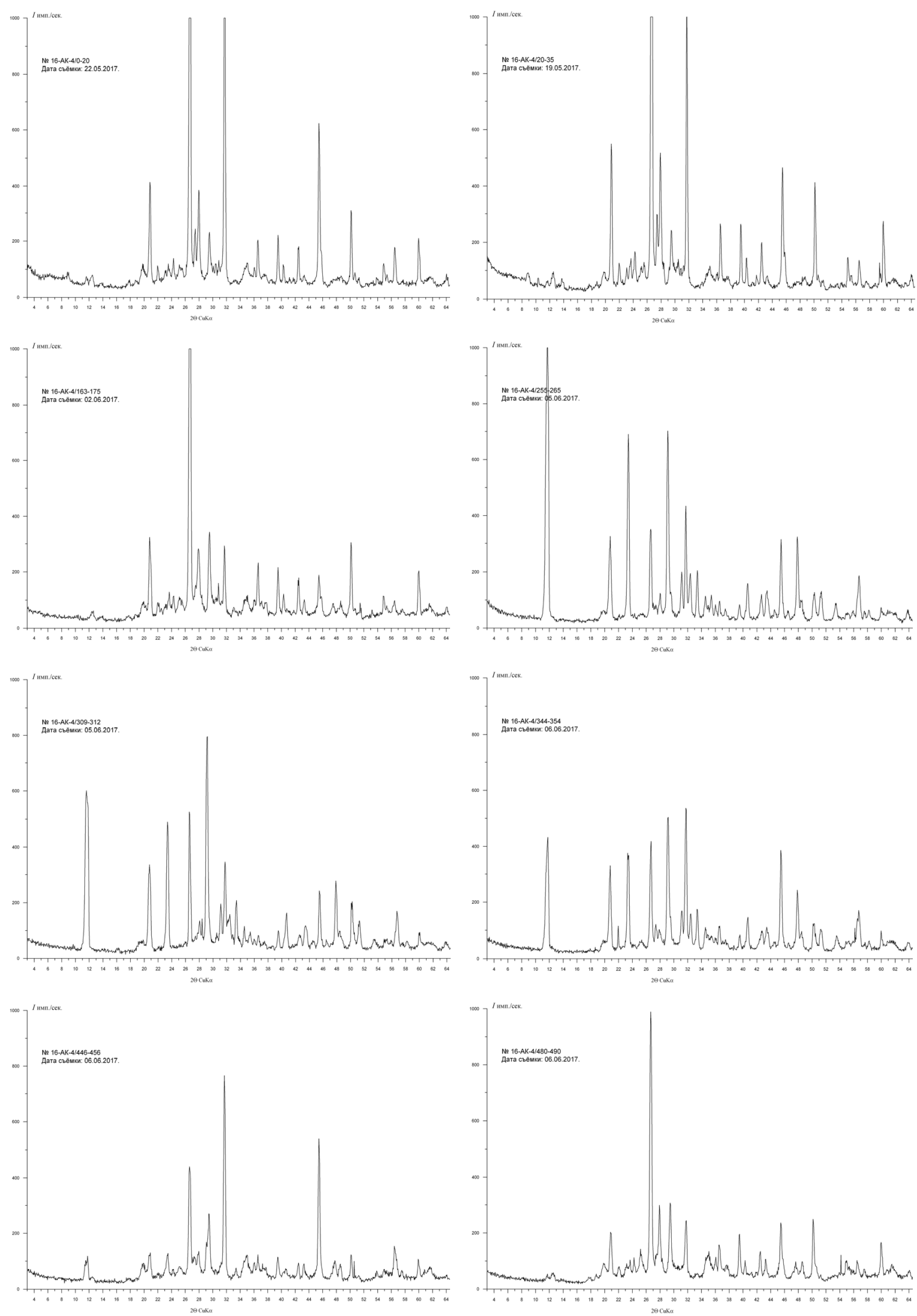

Figure 6. XRD spectra of Maloye Yarovoe lake's sediments on different depths (the depth values are in $\mathrm{cm}$ ). 



(a)
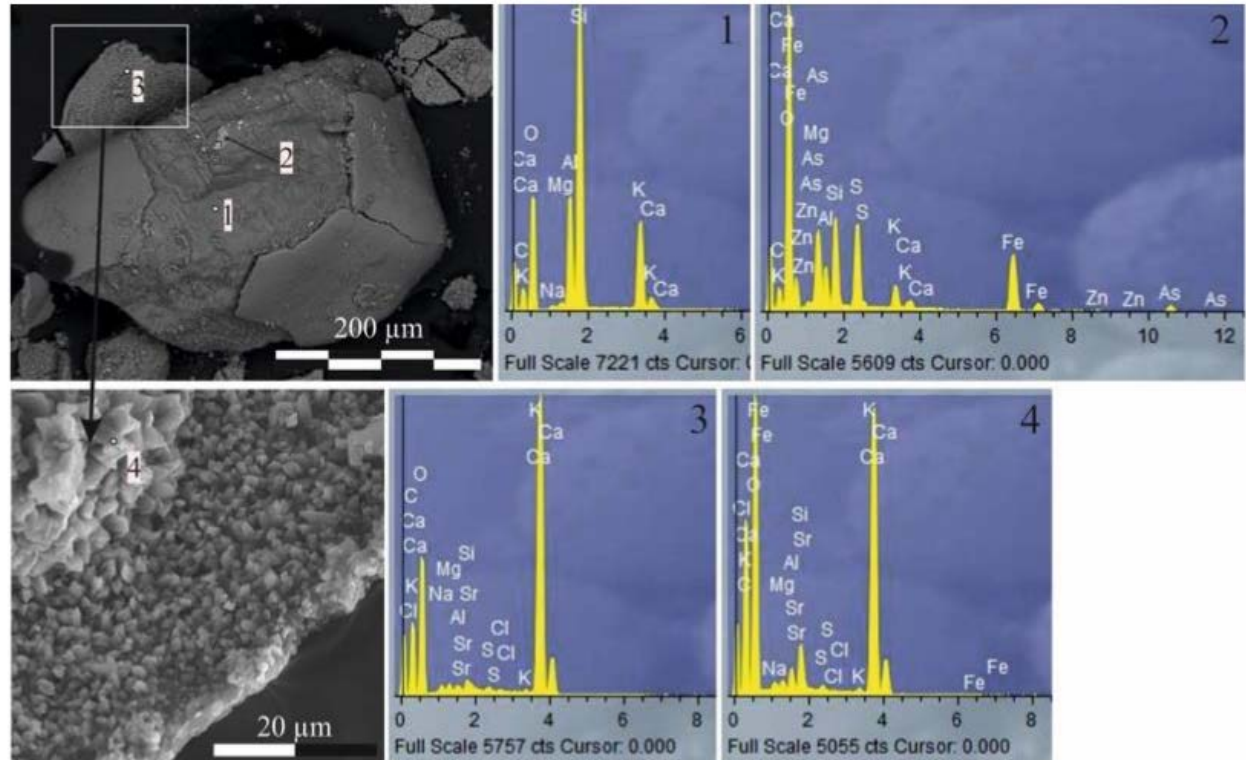

(b)
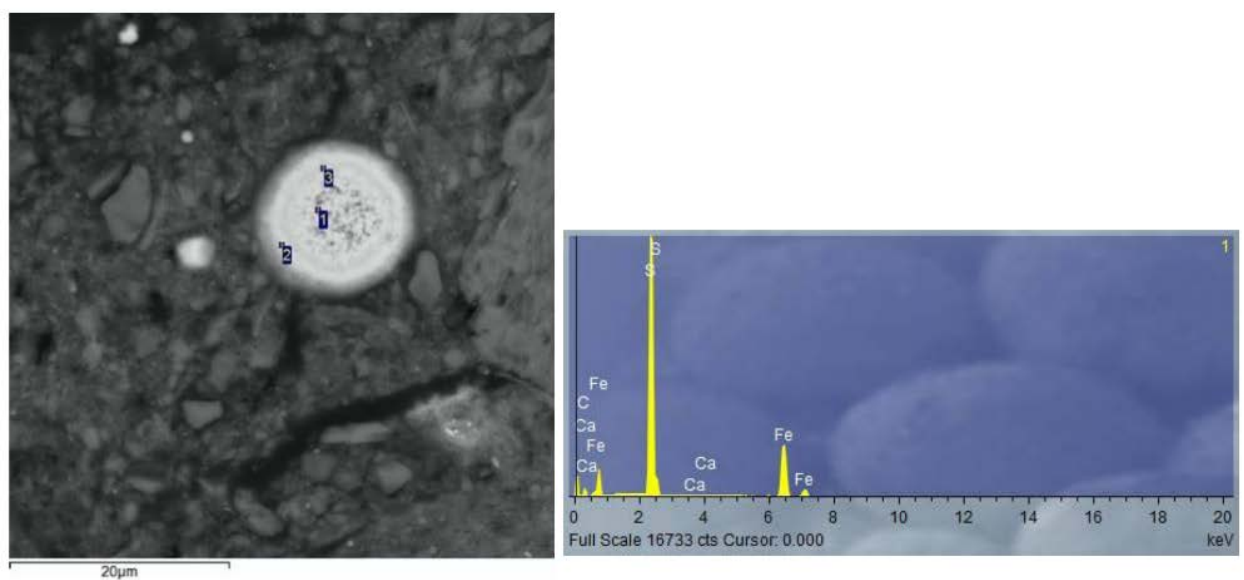

(c)

Figure 7. SEM images of: (a) anhydrite crystal (3.27-3.32 m); (b) the rounded feldspar grain (1) in a "shell" of calcium carbonate $(3,4)$ : mineral phase contains As $(3.06 \%)$, Zn (0.16\%) (0.6-0.7 m) and (c) Pyrite in framboid texture.

The upper half of the sediments united in the section 3 illustrates an increase in the shoreline erosion and corresponds to a "deep lake" stage. Clastic compound of mineral assemblages repeats the 
terrestrial clay material composition that is specified by the predominance of mica-hydromica and chlorites with the minimal amount of smectic phase [48]. As can be seen from Figure 5, the entire section 3 is sulfates-less. At the same time, there are peaks of a sharp increase in the organic content at the depths 1.0 and $1.9 \mathrm{~m}$ that can be indicated as a reflect to temporary changes in the state of lake ecosystem. The lowest salinity of the lake is at the section $3 a(1.6-2.25 \mathrm{~m} / 5.2-6.4 \mathrm{ka} \mathrm{BP})$ with high quantity of terrigenous material (mainly quartz and such aluminosilicate minerals as chlorites, K-fields) and less amount of organic and chemical components. Evaporites are represented by carbonates (mainly in form of calcite) and halite. The upper section $3 \mathrm{~b}(0-1.6 \mathrm{~m} / 0-5.2 \mathrm{ka} \mathrm{BP})$ is a muddy layer with the lowest amount of organic compound (13\%). Mineral composition is represented by high amount of clastic compound (feldspars, quartz), with lesser proportions of halite and low-magnesium calcite (LMg-calcite). The traces of dolomite and hematite were also detected. Figure $7 \mathrm{~b}$ illustrates the feldspar grain located inside the "shell" consisting of calcium carbonate crystals.

Pyrite is detected mainly in framboid textures and only in two layers enriched by $\mathrm{H}_{2} \mathrm{~S}$ according to the filed investigations (1.63-1.75 and 3.44-3.54 m, Figure 7c, Table S5) that indicates the existence of anoxic diagenesis. Unlike euhedral texture, framboidal pyrite is not believed to results from direct precipitation, but from the conversion of an FeS precursor [49]. Most authors believe that framboidal pyrite in bottom sediments is biogenic in origin since it was found that its formation associated with activity of sulfate-reducing microorganisms and microbial mats [50,51].

\subsubsection{Sequential Extractions}

Sequential extraction procedure that has the advantage of providing data on the specific forms of each metal and their behavior under various environmental conditions [52] was used in this study to determine the phase distribution and mobility of various elements in the sediments.

Since Maloye Yarovoe lake is of $\mathrm{Cl}-\mathrm{Na}$ type with a sharp prevalence of $\mathrm{Mg}$ over Ca (4 times), it is logical to start the description with sodium. Na content is stable along the core $(5 \pm 1 \%)$ with two peaks at $0.2 \mathrm{~cm}$ and $4.56 \mathrm{~m}$ (Figure $8 \mathrm{a}$ ) where halite is the main mineral phase based on the XRD results (Figure 6). Accordingly, sodium is leached in the form of water-soluble fractions. The residual fraction of Na comes from plagioclases.

As mentioned above, in the range of 300-350 cm, the proportion of authigenic minerals rises sharply to $50-70 \%$, however, the composition of the authigenic fraction is dictated mostly by the predominance of Ca-sulfates (Figure 5). Above and below this interval, more significant role plays Ca-carbonate influencing the behavior of calcium in the sediments.

The $\mathrm{Ca}$ and $\mathrm{SO}_{3}$ distributions (Figure $8 \mathrm{~b}$,e) also correlate to each over $\left(\mathrm{R}^{2}\right.$ is $\left.99 \%\right)$. The $\mathrm{SO}_{3}$ concentration increases from 2 to $22 \mathrm{mg} / \mathrm{kg}$, wherein Ca from 5-6 to $17 \mathrm{mg} / \mathrm{kg}$. The highest value of sulfates is detected in the section $2 \mathrm{~b}$ with the highest salinity. Their ratio sharply changes at the depth about $450 \mathrm{~cm}$, where sulfate disappears. Carbonate minerals formation varies along the depth, but never exceeds $25-26 \%$ of total authigenic part. The Mg-calcite peaks on XRD were caught only in the sections $2 \mathrm{~b}$ and $2 \mathrm{c}$ (high salinity layers); dolomite peaks—only in the section 3 of "deep lake" (see more detailed information about it in Section 4.1.2).

As can be seen from Figure 9, the logarithmic profiles of $\mathrm{Al}_{2} \mathrm{O}_{3}$ and $\mathrm{SiO}_{2}$ have analogous distributions along the core that can be explained by their common origin from terrigenous material of watershed area. The $\mathrm{Ca} / \mathrm{Mg}$ ratio (after calibrating Ca based on the amount needed for gypsum precipitation that is a common mineral along the whole sediment) also follows the path of $\mathrm{Al}$ and $\mathrm{Si}$ with some peaks at the depth of 2.6 (section $2 \mathrm{~b}$ ) and $3.2 \mathrm{~m}$ (section $2 \mathrm{c}$ ), where traces of hydroglauberite are detected indicating highest salinity period. The carbonates amount there is $8-11 \%$ which is the same or less than average for these layers (11-13\%). 


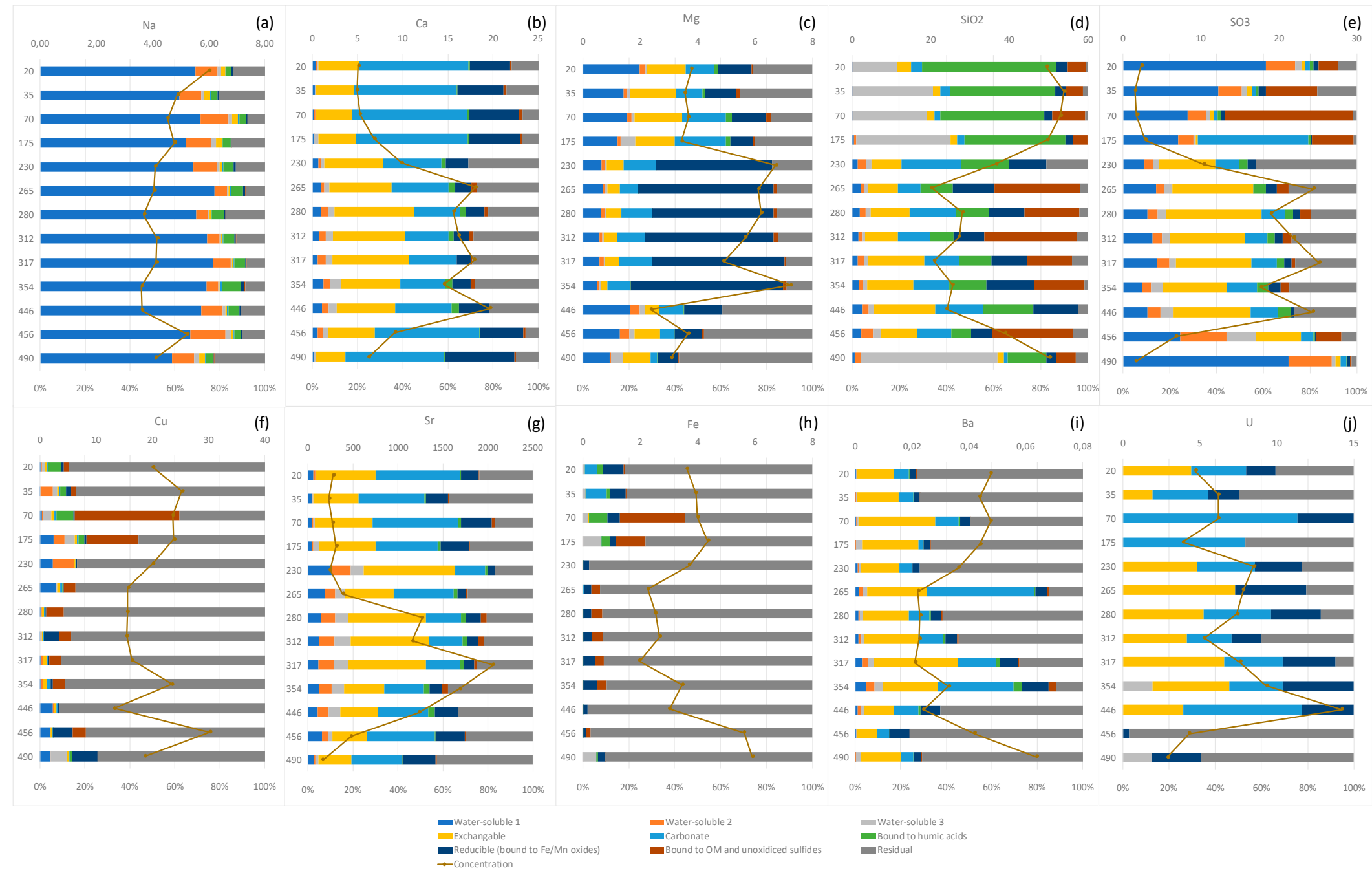

Figure 8. Vertical profiles ( $\mathrm{cm}$ ) of elements (in \%) extracted in the sequential extraction. The line represents element concentration is in $\mathrm{mg} / \mathrm{kg}$ units ( $\mathrm{Na}-(\mathbf{a}), \mathrm{Ca}-(\mathbf{b})$, $\mathrm{Mg}-(\mathbf{c}), \mathrm{SiO}_{2}-(\mathbf{d}), \mathrm{SO}_{3}-(\mathbf{e}), \mathrm{Cu}-(\mathbf{f}), \mathrm{Sr}-(\mathbf{g}), \mathrm{Fe}-(\mathbf{h}), \mathrm{Ba}-(\mathbf{i}), \mathrm{U}-(\mathbf{j})$. 


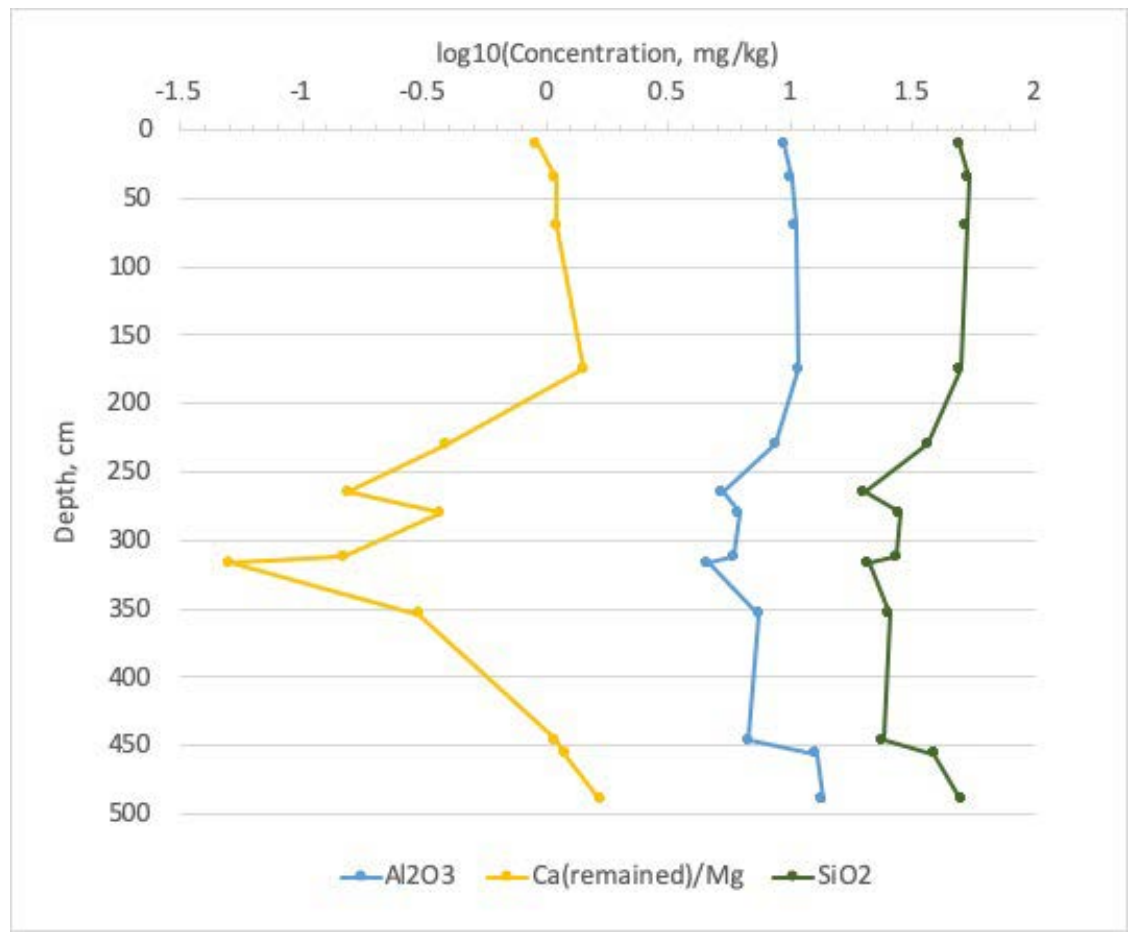

Figure 9. The logarithmic values of $\mathrm{SiO}_{2}, \mathrm{Al}_{2} \mathrm{O}_{3}$ concentrations and $\mathrm{Ca}$ (remained)/ $\mathrm{Mg}$ ratio. $\mathrm{Ca}$ (remained) was calculated by removing the amount of calcium needed for gypsum precipitation based on an average oxides composition of gypsum that is $32.57 \%$ of $\mathrm{CaO}, 46.5 \%$ of $\mathrm{SO}_{3}$, and $20.93 \%$ of $\mathrm{H}_{2} \mathrm{O}$.

In the upper part of the sediments calcium is leached in the exchangeable and carbonate forms (25\%). The similarity with the data of sedimentological analysis is clear: low-mineral (high-authigenic) part contains a high portion of calcium exchangeable fraction. This extraction step was performed using $1 \mathrm{M} \mathrm{NH}_{4} \mathrm{OAc}(\mathrm{pH} 7)$, however calcium is more likely associates with the dissolution of Gypsum at the next step ( $\mathrm{pH} 5$, extraction of potentially carbonate fraction) [53]. The water-soluble fraction at the depth of highest salinity (Table S7) is due to the presence of hydrogauberite $\mathrm{Na}_{10} \mathrm{Ca}_{3}\left(\mathrm{SO}_{4}\right)_{8} \cdot 6 \mathrm{H}_{2} \mathrm{O}$ and other soluble salts.

Strontium distribution along the sediments core is quite similar to Ca. The layer of $3.17 \mathrm{~m}$ is strongly enriched by $\mathrm{Sr}$ (Figure 8g). We associate the behavior of strontium with the formation of solid solutions of $(\mathrm{Ca}, \mathrm{Sr}) \mathrm{CO}_{3(\mathrm{~s})}$ type, however $\mathrm{XRD}$ analysis has not detected its presence in the sediments.

The $\mathrm{Mg}$ distribution along the core is not identical to $\mathrm{Ca}$ (Figure $8 \mathrm{~b}, \mathrm{c}$ ), although their total concentration peaks are quite similar in the section 2 (Table S7). In the upper part of the sediments Ca is leached in exchange and carbonate forms, magnesium, however, is found mostly in water-soluble, exchange and reducible fractions (3-4 times higher). The fact of higher concentrations in water of magnesium than calcium (up to 300 and $13,847 \mathrm{mg} / \mathrm{L}$, respectively) is due to higher solubility of its salts. Unlike the lake water $\mathrm{Mg} / \mathrm{Ca}$ ratio, the magnesium content in the bottom sediment is much lower. Thus, at the depth $2.30-3.54 \mathrm{~m}$, magnesium is bound to (hydro)oxides of iron and manganese. This is not a common fact, since $\mathrm{Mg}$ is not being adsorbed to the same extent as heavy metal ions. Moreover, the total iron content is the opposite to the magnesium content. The residual fraction proportion for magnesium is much higher-it is mainly chlorite, less is plagioclase.

The biogenic silicon fractionation is very diverse and varies depending on the sediment's composition [25]. The total concentration of $\mathrm{SiO}_{2}$ varies from 20 to $60 \mathrm{mg} / \mathrm{kg}$ (Figure 8d). At the first glance, its high amount correlates with higher percentage of water-soluble and bounded to humic acids fractions at section $3 b(0-1.6 \mathrm{~m})$. Indeed, the upper part of the sediments is black loam enriched with organic matter. This is the evidence that phytocenosis and microbiocenosis have already been 
developed here. At the same time, quartz is the part of terrigenous mineral released from the shoreline erosion (Table S5, Figure 6). Therefore, silicon fluctuations by three times may be due to a number of reasons [54]. In particular, dissolution of the major group of algae or silicification of carbonate, gypsum, and halite mineral phases result in high proportions of water-soluble silicon. At the same time, its low concentrations in solution $(1 \mathrm{mg} / \mathrm{L})$ are the result of formation and removal of $\mathrm{SiO}_{2}$ colloids or sorption of silicic acid by organic matter or hydroxides (exchangeable and other appropriate fractions). Considering the cyclicity of nutrients and their exchange at the water-sediment system, it can be concluded that part of dissolved silicon migrates from the surface sedimentary layer into near-bottom water [54]. In addition to this, there are evidence that microbial mats (actively growing in saline lake environments) besides having silica as a primary mineral phase can immediately replace associated mineral phases of water-soluble salt and carbonates [55]. This can explain the high proportion $(>50 \%)$ of water-soluble forms in the horizon of $4.90 \mathrm{~m}$.

The $\mathrm{Cu}$ distribution along the core is near stable $(13-30 \mathrm{mg} / \mathrm{kg}$ ) and in average $80 \%$ is detected as the residual fraction (Figure 8f). This is the main evidence that copper is inactive in the considered conditions. The noticeable binding of $\mathrm{Cu}$ to humid acids (HA) occurs only in the upper layers $(0-0.7 \mathrm{~m})$. Fraction of $\mathrm{Cu}$ associated with sulfides and organic matter (brown color) is detected mainly at the depth of $0.70-1.75 \mathrm{~m}$. This is a transition layer with the lowest salinity and high organic content (Figure $8 \mathrm{f}$ ). The proportion of reduced sulfur $\left(\mathrm{H}_{2} \mathrm{~S}, \mathrm{HS}^{-}\right)$in this layer is also substantial $(20-55 \%$, Table $\mathrm{S} 8)$ and two from three peaks of high organic content also occur in this layer (Figure 8f) that confirms the obtained results of $\mathrm{Cu}$ fractionation. It should also be said that pyrite was found in these layers (Table S5), which implies the presence of copper sulfides. The proportion of the exchangeable part of $\mathrm{Cu}$ is very low $(1 \%)$. The water-soluble fraction appears only in the layer with high salinity $(1.75-2.65 \mathrm{~m})$ and at the bottom of the sediments $(4.46-4.56 \mathrm{~m})$. The main forms of $\mathrm{Cu}$ in the subbase layer $(4.56-4.90 \mathrm{~m})$ are also mainly residual with relatively high proportion of water-soluble and reducible parts (bounded to Fe/Mn oxides).

Iron fractionation pattern is similar to copper (Figure $8 \mathrm{~h}$ ), only the proportion of residual part is larger, almost $90 \%$ (Table S8). In general, the iron content is low, only $4 \pm 1 \mathrm{mg} / \mathrm{kg}$, most of all in the Subbase horizon, i.e., terrigenous minerals. Looking at its content in the upper part of the sediments, it can be assumed that a minor migration of dissolved forms practically stops at the depth of $0.7-1.75 \mathrm{~m}$ where reducing conditions are created for the deposition of Pyrite and other sulfide minerals (fraction bound to $\mathrm{OM}$ and unoxidized sulfides).

As it turned out, the behavior of uranium (Figure 8j) is not controlled by the behavior of iron (due to sorption processes on ferrihydrite [56], precisely because iron is characterized by low mobility and presents in the residual fraction. Its content varies from 5 to $15 \mathrm{mg} / \mathrm{kg}$, with a maximum of $4.46 \mathrm{~m}$ in a layer that does not stand out with some distinctive features. Its high association with the carbonate fraction is predictable and varies from 20 to $75 \%$ (maximum in layers of $0.7,1.75$ and $4.46 \mathrm{~m}$ ), as well as exchangeable fractions. By the fact that in these parts the accumulation of organic and authigenic minerals is detected, the uranium was captured by organic material and in precipitated minerals. The highest part of residual U-form is in the subbase layer at $4.56 \mathrm{~cm}$ depth. We emphasize that in the studied system, uranium is much less conservative than copper and iron, i.e., exhibits diverse behavior in the solid phase of precipitation.

The elements such as $\mathrm{Cu}, \mathrm{Zn}, \mathrm{Rb}$, and $\mathrm{Y}$ also follows $\mathrm{Si}$ and $\mathrm{Al}$ paths (Figure 10, Table S6); their amount decreases during the high salinity period (section 2). 


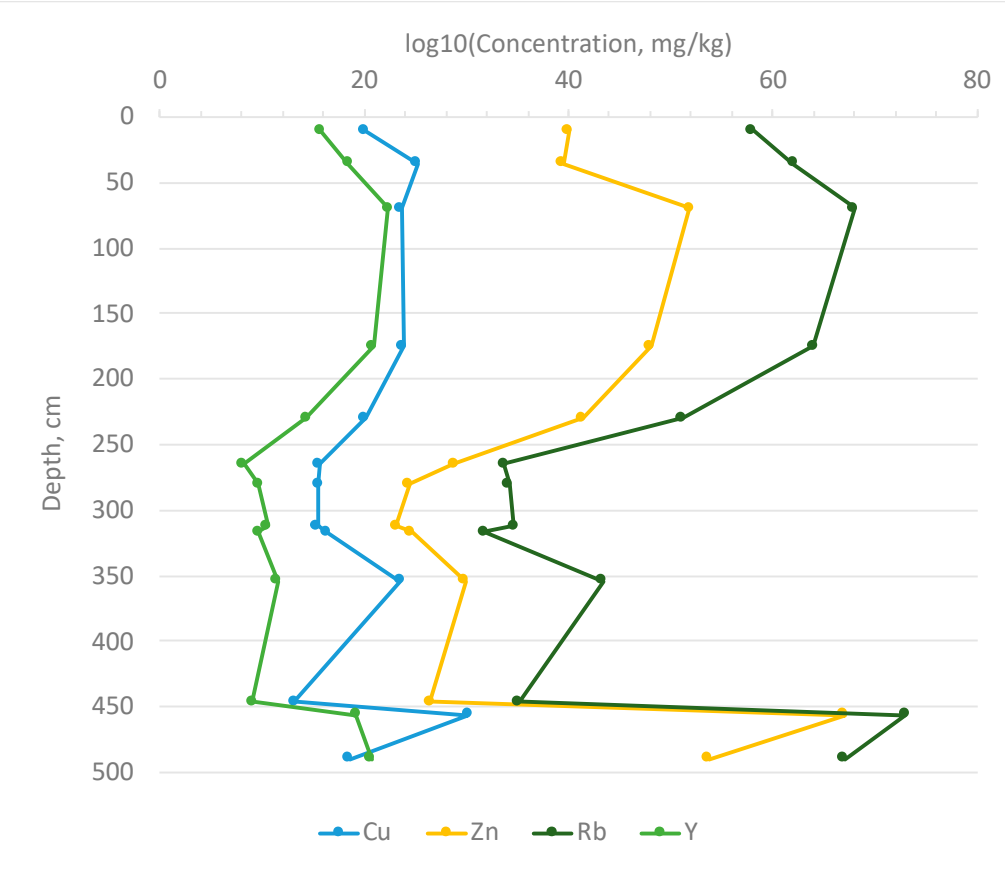

Figure 10. Trace elements $(\mathrm{Cu}, \mathrm{Zn}, \mathrm{Rb}, \mathrm{Y}, \mathrm{Pb})$ distribution along the sediments $(\mathrm{mg} / \mathrm{kg})$.

\subsection{Geochemical Modelling of Evaporite Sedimentation}

\subsubsection{Oxic Conditions of Lake-Water}

According to the modelling results, the chemical composition of Maloye Yarovoye Lake does not undergo significant changes during evaporation of up to $80 \%$ of water (Figure 11a). Since the initial solution with salinity of $220 \mathrm{~g} / \mathrm{L}$ (Cl-Na chemical type) is already in equilibrium state with respect to barite, quartz, kaolinite, magnesite-dolomite-huntite (Table S9), it can be suggested that up to nowadays evaporation pattern of the solution in the lake has been quite similar to the empirical observations for evaporation of seawater until halite precipitation [43]. At the last stages, epsomite and bischofite/carnalite could precipitate (Figure $11 \mathrm{~b},>80 \%$ of evaporation). Described evolution pattern is similar to the evaporation of seawater brines with some changes [57].

Since halite does not require high degree of supersaturation to precipitate [17] and $\mathrm{Na}^{+}$concertation in lake-water is high $(3.9 \mathrm{~mol} / \mathrm{L})$, the equilibrium state with it is established at the beginning of calculation ( $20 \%$ of $\mathrm{H}_{2} \mathrm{O}$ removal) and is remained until the latest stage of evaporation. The appearance of halite in the sediments is detected almost in all the sections, being the main mineral phase of the "deep lake". Due to the equilibrium with halite and Ca-Na sulfates, the sodium is constantly being removed from solution that leads to a change in the water chemical type from sodium chloride to magnesium chloride. Since the initial solution is $\mathrm{Cl}-\mathrm{Na}$ and remains the same along several last years (Table S2), obtained evolution path allows us to assume a low degree of concentration of the Maloye Yarovoe brines due to seasonal replenishment of the water reserves (mostly by melt water, rainfalls or groundwater).

Precipitation of gypsum or anhydrite (both at 0 and $25^{\circ} \mathrm{C}$ ) was appeared after removing more than $30 \%$ of $\mathrm{H}_{2} \mathrm{O}$ where the initial solution has accumulated high enough concentrations of $\mathrm{Ca}^{2+}$ and $\mathrm{SO}_{4}{ }^{2-}$ ( 0.012 and 0.2 moles respectively). Mineralogical study supported gypsum/anhydrite precipitation during the "shallow lake" (2.2-4.6 m) stage. In some cases, strontium can replace calcium in gypsum forming celestite (celestite log SI is $\sim 0$, Table S9).

After nearly $50 \%$ of $\mathrm{H}_{2} \mathrm{O}$ removal, the solution is oversaturated with respect to glauberite $\mathrm{Na}_{2} \mathrm{Ca}\left(\mathrm{SO}_{4}\right)_{2}$ and hydroglauberite $\mathrm{Na}_{10} \mathrm{Ca}_{3}\left(\mathrm{SO}_{4}\right)_{8} \cdot 6 \mathrm{H}_{2} \mathrm{O}$ that corresponds to the stage of double Ca-Na sulfate salts. Indeed, they are found in sediments of the Maloe Yarovoye Lake. Babel and Schreiber [46] highlighted that Gypsum crystallization varies depending on Halite quantity or water salinity and it 
grows as fine-grained or crystal forms. The growth of the crystals (which can be more than $2 \mathrm{~mm}$ ) is called 'selenite' and is determined by microbial activity (mainly in presence of organic mat).

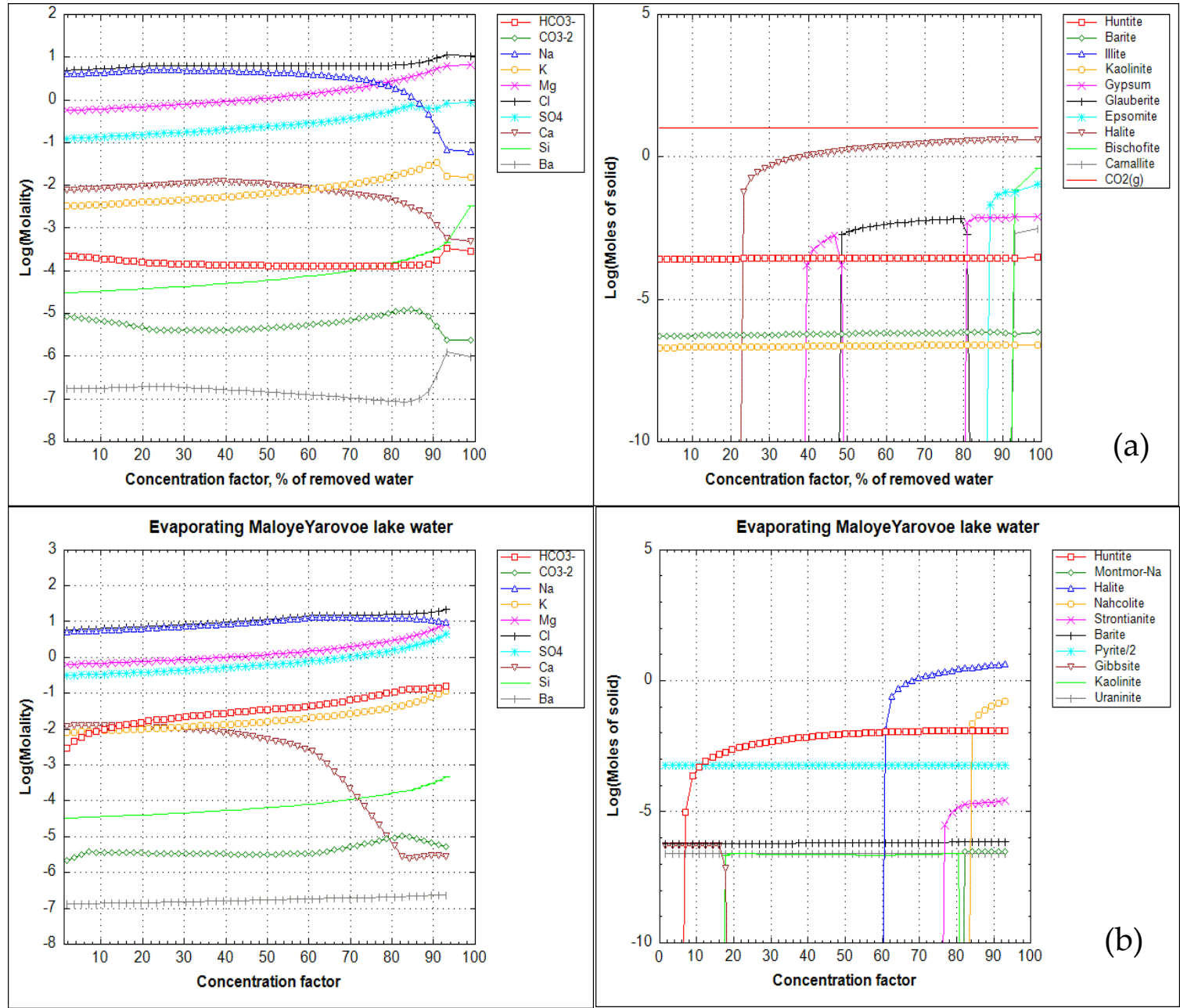

Figure 11. Evaporation trends of lake water chemical composition and mineral assemblages in oxicconditions (upper panel-a) and in reducing condition and presence of organic matter (lower panel-b).

The next stage of mineral formation is epsomite $\mathrm{MgSO}_{4} \cdot 7 \mathrm{H}_{2} \mathrm{O}$. According to [43], mirabilite can forego its crystallization, however, none of these minerals are detected in the sediments. As mentioned above, though carnallite $\mathrm{KMgCl}_{3}: 6 \mathrm{H} 2 \mathrm{O}$ and bischofite $\mathrm{MgCl}_{2}: 6 \mathrm{H} 2 \mathrm{O}$ appear on the latest stages of evaporation modelling, the data cannot be considered as reliable since the limitations of Pitzer approach for solutions with high ionic strength. Both salts are not detected by mineralogical analysis. However, if the halite formation is prohibited in the modelling, thenardite $\mathrm{Na}_{2} \mathrm{SO}_{4}$ appears. The mineralogical studies show it is between $3.00-3.40 \mathrm{~m}$ in depth.

\subsubsection{Reducing Conditions of Lake-Water}

The evaporation path of the Maloye Yarovoe lake under reducing conditions is different from oxic ones (Figure 11b). The halite precipitation starts on much later stages in comparison with oxic conditions ( $60 \%$ of evaporation) and gypsum is absent in the model associations. Because of constant increase of carbonates in evaporated solution due to organic matter degradation, the latest stages of evaporation are also distinguished with nahcolite $\mathrm{NaHCO}_{3}$ and strontianite precipitation. Higher bicarbonate ion content allows also more carbonates to precipitate (calcite, huntite) that leads to a 
sharp decrease of calcium in water. Indeed, $\mathrm{Ca}^{2+}$ concentrations in the Kulunda lakes water are usually small and only replenished by the inflow of atmospheric- or groundwaters. The mineral equilibria assemblages are marked by iron and uranium minerals (pyrite, uraninite) forming under anoxic conditions.

\section{Discussion}

\subsection{Factors Controlling the Chemical Evolution of Brines}

Based on the previous section, there are several major factors which have been controlling the chemical evolution of Maloye Yarovoe Lake over the years. All of them are tightly coupled to each over and their following subdivision is blurred and discussible.

\subsubsection{Water-Rock Interaction and Evaporation}

As was mentioned before, the evaporation rate of the lake system environment varied over the evolution path, so two main sections of the sediments were detected along the core: the stages of "shallow" and "depth" lake. According to the data of radiocarbon dating, the most significant changes in the level of water and the transition from one state to another occurred at c. $7.5 \mathrm{ka}$ BP $(2.25-2.5 \mathrm{~cm})$. This time period has already been mentioned as a cross-over interval from cold-dry to warm-moist period [58]. Indeed, the possibility of lake desiccation is supported by the changes in elements fractionation in the sediments. High concentrations of sulfates together with $\mathrm{Ca}, \mathrm{Mg}, \mathrm{Sr}$ indicate more intense processes of lake desiccation and salt crystallization before the $7.5 \mathrm{ka}$ BP period. Ca-Na bearing phases of sulfates (with possible replacement by $\mathrm{Sr}$ ) are the most common minerals of the desiccation period. Later, along with temperature rise and the beginning of early diagenesis processes, some sulfates transformed into anhydrite which usually does not precipitate directly during evaporation. It is a known fact, that anhydrite forms by dehydration of precursor gypsum precipitates and considered to be a diagenetic mineral [59].

The described shift in water levels causes the changes in water-rock interaction processes. Since many minerals forming under described conditions of intense evaporation are not stable and can easily precipitate and dissolve depending on temperature fluctuations, moisture ratio, and $\mathrm{pH}$-Eh conditions, there is no a fine line between these two stages of the lake. Moreover, seasonal changes blurring the transaction even more. In particular, summer seasons with high temperature and intense evaporation lead to reduced solubility indexes of carbonates and sulfates, thus cooler and humid winters lead to precipitation of water-soluble salts of $\mathrm{Na}$ and $\mathrm{Mg}$ chlorides [60].

\subsubsection{Biogeochemical Processes}

The absence of dolomite formation might be explained by biogeochemical processes in saline lakes. Being controlled by dissolved sulfate content and OM degradation (in particular, sulfur reduction) "conditions for formation of Gypsum exclude those for formation of dolomite and vice versa" [61]. According to our previous studies [27], Kulunda saline lakes have hydrogen sulfide in both water layer and bottom sediments formed due to sulfates reduction processes and precipitates from the solution in the form of various iron sulfides (i.e., in our case, pyrite). Absolutely, high salinity of water restricts the intensity of sulfate reduction in such chloride lakes as Maloye Yarovoe lake, but, nevertheless, the level of organic matter accumulation is intense and both bacterial reduction of sulfates and secondary mineralization determine the behavior of sulfur in the lakes [27] and can be considered as diagenesis markers.

Since solubility of gypsum significantly increases with the rise of $\mathrm{NaCl}$ concentration in solutions, chloride-sodium brines have a tremendous ability to accumulate sulfate ions which are later reduced by sulfate-reducing bacteria (under anaerobic environment and in the presence of organic substances such as aldehydes, fatty acids, ketones, etc.) to hydrogen sulfide form together with other reduced 
sulfur forms (thiosulfate, sulfite, polythionate). Ultimately, the sulfate reduction equation will look like this:

$$
\mathrm{CaSO}_{4} \cdot 2 \mathrm{H}_{2} \mathrm{O}+\mathrm{TOC}+\mathrm{H}_{2} \mathrm{O}=\mathrm{CaCO}_{3}+\mathrm{H}_{2} \mathrm{~S}+\mathrm{CO}_{2}+2 \mathrm{H}_{2} \mathrm{O}
$$

Therefore, it turns out that in the presence of sulfate reduction in the lake, gypsum can be a source of calcium for carbonates, hence the mirror-symmetric character of the distribution of gypsum and calcite content in sediments is manifested.

On the other hand, the main product of the sulfate reduction process is hydrogen sulfide that reacts with iron and, firstly, is being removed into bottom sediments in the form of iron monosulfide and, secondly, converts it into pyrite. Both of these stages consider the presence in the solution of elemental sulfur which is involved in pyritization process. Thiosulfate can also act as a carrier of elemental sulfur; the presence of these compounds has been confirmed by analytical methods [27]. Then the process of pyrite formation can be described by the following equation:

$$
\mathrm{FeS}+\mathrm{S}_{2} \mathrm{O}_{3}{ }^{2-}=\mathrm{FeS}_{2}+\mathrm{SO}_{3}{ }^{2-}
$$

A similar scheme is realized when hydrogen sulfide interacts with iron under anaerobic conditions. The formation of pyrite in aerobic-anaerobic conditions of the upper layer of bottom sediments can be represented as the following reactions:

$$
\begin{gathered}
2 \mathrm{FeOOH}+4 \mathrm{HS}^{-}+4 \mathrm{H}^{+}+\frac{1}{2} \mathrm{O}_{2}=2 \mathrm{FeS}_{2}+5 \mathrm{H}_{2} \mathrm{O} \\
\mathrm{Fe}^{2+}+2 \mathrm{HS}^{-}+\frac{1}{2} \mathrm{O}_{2}=\mathrm{FeS}_{2}+\mathrm{H}_{2} \mathrm{O}
\end{gathered}
$$

Hence, pyrite is present in the bottom sediments, regardless of redox conditions.

The change from reduced to oxic environment leads to the oxidation of hydrogen sulfide, sulfides and intermediate sulfur compounds and is carried out by both chemical and microbiological reactions. The final oxidation products in such reactions are sulfate ions or elemental sulfur depending on the intake of hydrogen sulfide from the anaerobic zone or by the need for oxygen inflow from the overlying oxidation zone:

$$
\begin{aligned}
& 2 \mathrm{H}_{2} \mathrm{~S}+\mathrm{O}_{2} \rightarrow 2 \mathrm{~S}^{0}+2 \mathrm{H}_{2} \mathrm{O} \\
& \mathrm{H}_{2} \mathrm{~S}+2 \mathrm{O}_{2} \rightarrow \mathrm{SO}_{4}{ }^{2-}+2 \mathrm{H}^{+}
\end{aligned}
$$

Obviously, there are several different sources of OM in lake waters and bottom sediments (organic detrite, bacterial photosynthesis) and their biological activity affects drastically not only the migration features of elements, but also the types of mineral crystallization.

\subsubsection{Stability of Chemical State}

The last, but not the least important factor of geochemical balance is water discharge. Unfortunately, the Altai region groundwaters of different geological periods has not received much studying since 70s which make it difficult to estimate their influence on lakes' water balance and geochemical state depending on the distance from the lakes. According to some recent data, groundwaters of Kulunda steppe differ in their chemical composition [62]; $\mathrm{Na}, \mathrm{Cl}$ and $\mathrm{SO}_{4}$-ions increase their proportion in the direction to lower altitude values indicating the presence of active salinization.

As was described before, pore-waters chemical composition is very different from shallow and deep layers of the sediments, reaching more than four-times difference in salinity (Table S2). The lower values of $\mathrm{Na}$ and $\mathrm{Mg}$ in deeper pore waters indicates that during filtration processes into deeper layer pore waters become more adjustable to the environment and composition of groundwaters of the region. At the same time, higher values of $\mathrm{Al}$ and $\mathrm{Si}$ in deeper layers might be a sign of more intense interaction with silicate minerals. According to the data of sedimentological analysis this layer is characterized by higher amount of terrigenous material in the sediments which is brought from the 
watershed area during shoreline erosion. Thus, these waters could be either the buried waters which were formed during the inception of "deep lake" period (section $3 \mathrm{~b}$ ) or formed as a mixture of saline filtered waters with groundwaters of lower salinity.

Recent studies show that desertification processes developing in the region drastically increase soil degradation and wind erosion of land. Moreover, water table is constantly dropping due to increase of water household usage and overall decrease of the thickness of snow layer during winter [63]. All of these factors affect the sensitive balance of saline lakes ecosystem, changing the ratio between precipitation inflow, groundwater discharge and level of evaporation, leading in some cases to the total desiccation of lakes.

\section{Conclusions}

The article presents a detailed hydrogeochemical study of water and sediment geochemistry of the endorheic Maloye Yarovoe lake ecosystem. The lake is located in the semi-arid landscape of Kulunda steppe (south of Western Siberia) and represents the most widespread chemical type of saline lake on the territory (Cl-Na). Water environment of the lake is characterized by neutral to base $\mathrm{pH}$ (7.75) and nearoxic (Eh is $45-60 \mathrm{mV}$ ). Major and trace element chemistry studied in lake and pore water is different showing the reduce in $\mathrm{Na}$ and $\mathrm{Mg}$ accumulation in deep pore waters probably due to the dissolution by less saline groundwaters.

Bottom sediments of the lake have been formed during two main stages of "shallow" and "deep" lake. Shallower lake period $(2.25-4.57 \mathrm{~m})$ is represented by intense level of evaporation accompanied by the precipitation of such minerals as Ca-sulfates, halite, thernadite, and calcite. During the deeper lake period (0-2.25 m, after sharp changes in water balance of the lake caused by water input increase) mineral assemblages are characterized by the absence of Ca-sulfates and are presented mostly by halite, calcite and silicate minerals. The subbase layer $(4.57-4.97 \mathrm{~m})$ consists of silicate minerals with some halite and calcite traces. Each of the stages corresponds to the specific conditions of the ecosystem geochemical balance with the transaction (during $6.4 \mathrm{ka} \mathrm{BP}$ ) from the warm-dry period to warm-wet period of present days.

The data of elements fractionation along the core and their behavior also point to the changes of geochemical balance during these two periods. High proportions of water-soluble and exchange fraction during high salinity period of intense evaporation versus increased inflow of residual fraction during water level increase and shoreline destruction indirectly specify the differences between "shallow" and "deep" lakes stages. Moreover, fractions of bounding with $\mathrm{OM}, \mathrm{Fe} / \mathrm{Mn}$ oxides or unoxidized sulfides show that there were also some periods of organic enrichment that triggered the processes of early diagenesis in sediments.

We underline that described transactions of geochemical balance of the lake are mainly due to the changes in water-rock interaction and evaporation processes combined with constantly active biogeochemical processes.

Supplementary Materials: The following are available online at http://www.mdpi.com/2073-4441/12/11/3001/s1. Table S1: details for sequential extraction procedure; Table S2: chemical composition of lake- and pore-water; Table S3: trace elements composition of lake- and pore-water $(\mathrm{mg} / \mathrm{L})$; Table S4: sedimentological analysis of sediments; Table S5. XRD measurements of sediments (depth range in $\mathrm{cm}$ ); Table S6: the elemental composition of the sediments; Table S7: mineral composition of major sections of sediments (see Figure 3 and Table S3 for more details); Table S8: sequential extraction fractionation of elements; and Table S9: the results of evaporation modelling in oxic and anoxic conditions performed in Phreeqc.

Author Contributions: Writing-original draft preparation, M.K.; writing-review and editing, O.G. and S.B.; visualization, M.K.; methodology and formal analysis, O.N., S.K. and N.R. All authors have read and agreed to the published version of the manuscript.

Funding: The reported study was funded by Russian Foundation for Basic Research (RFBR, project № 20-35-70052) and the State Assignment of the Institute of Geology and Mineralogy SB RAS. For S.K. the study was supported by the Russian Foundation for Basic Research (grants NO. 19-29-05085 and NO. 19-05-00403); N.R. worked in the frame of project NIR NO. 0264-2019-0010.

Conflicts of Interest: The authors declare no conflict of interest. 


\section{References}

1. Donchyts, G.; Baart, F.; Winsemius, H.; Gorelick, N.; Kwadijk, J.; Van De Giesen, N. Earth's surface water change over the past 30 years. Nat. Clim Chang. 2016, 6, 810-813. [CrossRef]

2. Erler, A.R.; Frey, S.K.; Khader, O.; d'Orgeville, M.; Park, Y.-J.; Hwang, H.-T.; Lapen, D.R.; Peltier, W.R.; Sudicky, E.A. Simulating Climate Change Impacts on Surface Water Resources Within a Lake-Affected Region Using Regional Climate Projections. Water Resour. Res. 2018, 55. [CrossRef]

3. Maberly, S.C.; O’Donnell, R.A.; Woolway, R.I.; Cutler, M.E.; Gong, M.; Jones, I.D.; Merchant, C.J.; Miller, C.A.; Politi, E.; Marian Scott, E. Global lake thermal regions shift under climate change. Nat. Commun. 2020, 11, 1232. [CrossRef]

4. Jones, B.F.; Naftz, D.L.; Spencer, R.J.; Oviatt, C.G. Geochemical evolution of Great Salt Lake, Utah, USA. Aquat. Geochem. 2009, 15, 95-121. [CrossRef]

5. Tweed, S.; Grace, M.; Leblanc, M.; Cartwright, I.; Smithyman, D. The individual response of saline lakes to a severe drought. Sci. Total Environ. 2011, 409, 3919-3933. [CrossRef] [PubMed]

6. Wahed, A.M.S.M.; Mohamed, E.A.; El-Sayed, M.I.; M'nif, A.; Sillanpää, M. Geochemical modeling of evaporation process in Lake Qarun, Egypt. J. Afr. Earth Sci. 2014, 97, 322-330. [CrossRef]

7. Boros, E.; Horváth, Z.; Wolfram, G.; Vörös, L. Salinity and ionic composition of the shallow astatic soda pans in the Carpathian Basin. Ann. De Limnol. Int. J. Limnol. 2014, 50, 59-69. [CrossRef]

8. Deocampo, D.; Jones, B. Geochemistry of Saline Lakes. In Treatise on Geochemistry. Volume 7: Surface and Groundwater, Weathering, and Soils, 2nd ed.; Drever, J.I., Ed.; Elsevier: Amsterdam, The Netherlands, 2014; Chapter 7.13. [CrossRef]

9. Pitzer, K.S. Activity Coefficients in Electrolyte Solutions, 2nd ed.; CRC Press: Boca Raton, FL, USA, 1991.

10. Lassin, A.; André, L.; Lach, A. Considerations about the Building of a Thermodynamic Database for the Chemical Description of Highly Saline Systems. Procedia Earth Planet. Sci. 2017, 17, 304-307. [CrossRef]

11. Wollast, R.; Chou, C. The carbon cycle at the ocean margin in the northern Gulf of Biscay. Deep Sea Res. 2001, 48, 3265-3293. [CrossRef]

12. Berg, G.M.; Balode, M.; Purina, I.; Bekere, S.; Bechemin, C.; Maestrini, S.Y. Plankton community composition in relation to availability and uptake of oxidized and reduced nitrogen. Aquat. Microb. Ecol. 2003, 30, $263-274$. [CrossRef]

13. Middelburg, J.J. Reviews and syntheses: To the bottom of carbon processing at the seafloor. Biogeosciences 2018, 15, 413-427. [CrossRef]

14. Mianping, Z. Classification of Saline Lakes and Types of Mineral Deposit. In An Introduction to Saline Lakes on the Qinghai-Tibet Plateau; Monographiae Biologicae; Springer: Dordrecht, The Netherlands, 1997; Volume 76.

15. Berner, R.A. Principles of Chemical Sedimentology; McGraw-Hill: New York, NY, USA, 1971; 240p.

16. Jorgensen, B.B. Processes at the sediment-water interface. In The Major Biochemical Cycles and Their Interactions; Bolin, B., Cook, R.B., Eds.; John Wiley: New York, NY, USA, 1983; pp. 477-515.

17. Santschi, P.H.; Höhener, P.P.; Benoit, G.; Buchholtz-ten Brink, M. Chemical Processes at the Sediment-Water Interface. Mar. Chem. 1990, 30, 269-315. [CrossRef]

18. Canfield, D.; Raiswell, R.; Bottrell, S.H. The reactivity of sedimentary iron minerals toward sulfide. Am. J. Sci. 1992, 292, 659-683. [CrossRef]

19. Chilingar, G.V.; Larsen, G. Diagenesis in Sediments and Sedimentary Rocks; Elsevier: Amsterdam, The Netherlands, 1983; Volume 2.

20. Davydova, N.; Subetto, D.; Belkina, N.; Simola, H.; Kukkonen, M. Paleolimnology and sediments of Lake Ladoga: Monitoring programmer proposal. Environ. Monit. Lake Ladoga. Joensuu 2000, 1, 68-74.

21. Belkina, N. Changes in the Processes of Redox Diagenesis of Bottom Sediments of Onega and Ladoga lakes under the Influence of Anthropogenic Factors. Ph.D. Thesis, Northern Water Problems Institute Karelian Research Centre Russian Academy of Science, Saint-Petersburg, Russia, 2003; 149p. (In Russian).

22. Muller, B.; Maerki, M.; Schmid, M.; Vologina, E.G.; Wehrli, B.; Wüest, A.; Sturm, M. Internal carbon and nutrient cycling in Lake Baikal: Sedimentation, upwelling, and early diagenesis. Glob. Planet. Chang. 2005, 46, 101-124. [CrossRef]

23. Gaskova, O.L.; Strakhovenko, V.D.; Ermolaeva, N.I.; Zarubina, E.Y.; Ovdina, E.A. A simple method to model the reduced environment of lake bottom sapropel formation. Chin. J. Ocean. Limnol. 2017, 35, 956-966. [CrossRef] 
24. Leonova, G.A.; Mal'tsev, A.E.; Melenevskii, V.N.; Miroshnichenko, L.V.; Kondrat'eva, L.M.; Bobrov, V.A. Geochemistry of Diagenesis of Organogenic Sediments: An Example of Small Lakes in Southern West Siberia and Western Baikal Area. Geochem. Int. 2018, 56, 344-361. [CrossRef]

25. Strakhovenko, V.D.; Shcherbov, B.L.; Malikova, I.N.; Vosel', Y. The regularities of distribution of radionuclides and rear-earth elements in bottom sediments of Siberian lakes. Russ. Geol. Geophys. 2010, 51, 1167-1178. [CrossRef]

26. Zhdanova, A.N.; Solotchina, E.P.; Krivonogov, S.K.; Solotchin, P.A. Mineral Composition of the Sediments of Lake Malye Chany as an Indicator of Holocene Climate Changes (Southern West Siberia). Russ. Geol. Geophys. 2019, 60, 1163-1174.

27. Borzenko, S.V.; Kolpakova, M.N.; Shvartsev, S.L.; Isupov, V.P. Biogeochemical conversion of sulfur species in saline lakes of Steppe Altai. J. Oceanol. Limnol. 2018, 36, 676-686. [CrossRef]

28. Lebedeva Verba, M.P.; Lopukhina, O.V.; Kalinina, N.V. Specificity of the chemical and mineralogical composition of salts in solonchak playas and lakes of the Kulunda steppe. Eurasian Soil Sci. 2008, 41, 416-428. [CrossRef]

29. Rudaya, N.; Nazarova, L.; Nourgaliev, D.; Palagushkina, O.; Papin, D.; Frolova, L. Mid-late Holocene environmental history of Kulunda, southern West Siberia: Vegetation, climate and humans. Quat. Sci. Rev. 2012, 48, 32-42. [CrossRef]

30. Zarubina, E.Y.; Durnikin, D.A. Flora of saline lakes of Kulunda steppe (south of Western Siberia). Sib. Ecol. J. 2005, 2, 341-351. (In Russian)

31. Kuznetsova, M.A.; Postnikova, O.V.; Sidorenkov, A.V. Hydrogeology of USSR; Nedra: Moscow, Russia, 1972; Volume 17, p. 344. (In Russian)

32. Slyadnev, A. Climate of Altay Kray; Altai knizhnoye izdatel'stvo: Barnaul, Russia, 1958; 139p. (In Russian)

33. Maximova, N.; Kantamaneni, K.; Morkovkin, G.; Arnaut, D.; Rice, L. The transformation of agro-climatic resources of the altai region under changing climate conditions. Agriculture 2019, 9, 68. [CrossRef]

34. Roshydromet. A Report on Climate Features on the Territory of the Russian Federation in 2018. 2019. 79p. Available online: https://meteoinfo.ru/images/media/climate/rus-clim-annual-report.pdf (accessed on 22 September 2020).

35. Kolpakova, M.N.; Gaskova, O.L.; Naymushina, O.S.; Karpov, A.V.; Vladimirov, A.G.; Krivonogov, S.K. Saline lakes of Northern Kazakhstan: Geochemical correlations of elements and controls on their accumulation in water and bottom sediments. Appl. Geochem. 2019, 107, 8-18. [CrossRef]

36. Rudaya, N.; Krivonogov, S.; Słowiński, M.; Cao, X.; Zhilich, S. Postglacial history of the Steppe Altai: Climate, fire and plant diversity. Quat. Sci. Rev. 2020. accepted.

37. Dauvalter, V.A.; Rognerud, S. Heavy metal pollution in sediments of the Pasvik River drainage. Chemosphere 2001, 42, 9-18. [CrossRef]

38. Tessier, A.; Cambell, P.G.; Bisson, M. Sequential extraction procedure for the speciation of particulate trace metals. Anal. Chem. 1979, 51, 844-851. [CrossRef]

39. Bogush, A.A.; Lazareva, E.V. Behavior of heavy metals in sulfide mine tailings and bottom sediment (Salair, Kemerovo region, Russia). Environ. Earth Sci. 2011, 64, 1293-1302. [CrossRef]

40. Duarte, C.M.; Prairie, Y.T.; Montes, C.; Cole, J.J.; Striegl, R.; Melack, J.; Downing, J.A. CO 2 emissions from saline lakes: A global estimate of a surprisingly large flux. J. Geophys. Res. Biogeosci. 2008, 113. [CrossRef]

41. Goldschmidt, V.M. The principles of distribution of chemical elements in minerals and rocks. J. Chem. Soc. 1937, 74, 655-673. [CrossRef]

42. Hardie, L.A.; Eugster, H.P. The Evolution of Closed-Basin Brines. Miner. Soc. Am. Spec. Publ. 1970, 3, $273-290$.

43. Babel, M.; Schreiber, B.C. Geochemistry of Evaporites and Evolution of Seawater. In Treatise on Geochemistry, 2nd ed.; Elsevier: San Diego, CA, USA, 2014; Volume 9.

44. Kolpakova, M.N.; Gaskova, O.L. Major ions behaviour during evaporation of different saline type water of Western Mongolian lakes (geochemical modelling). Hydrol. Res. 2018, 49, 163-176. [CrossRef]

45. Parkhurst, D.L.; Appelo, C.A. Description of Input and Examples for PHREEQC Version 3-A Computer Program. for Speciation, Batch-Reaction, One-Dimensional Transport, and Inverse Geochemical Calculations; U.S. Geological Survey Techniques and Methods: Denver, CO, USA, 2013; 497p.

46. Gas'kova, O.L.; Strakhovenko, V.D.; Ovdina, E.A. Composition of brines and mineral zoning of the bottom sediments of soda lakes in the Kulunda steppe (West Siberia). Russ. Geol. Geophys. 2017, 58, 1207-1218. [CrossRef] 
47. Rudaya, N.; Zhilich, S. Changes in Annual Precipitation in the Younger Dryas and Holocene in Southwestern Siberia. Probl. Archaeol. Ethnogr. Anthropol. Sib. Neighboring Territ. 2019, 25, 211-217. [CrossRef]

48. Chizhikova, N.P.; Khitrov, N.B. Diversity of clay minerals in soils of solonetzic complexes in the southeast of Western Siberia. Eurasian Soil Sci. 2016, 49, 1419-1431. [CrossRef]

49. Raiswell, R. Pyrite texture, isotopic composition and the availability of iron. Am. J. Sci. 1982, 1, $1244-1263$. [CrossRef]

50. Picard, A.; Gartman, A.; Clarke, D.R.; Girguis, P.R. Sulfate-reducing bacteria influence the nucleation and growth of mackinawite and greigite. Geochim. Cosmochim. Acta 2018, 220, 367-384. [CrossRef]

51. Popa, R.; Kinkle, B.K.; Badescu, A. Pyrite Framboids as Biomarkers for Iron-Sulfur Systems. Geomicrobiol. J. 2004, 21, 193-206. [CrossRef]

52. Hass, A.; Fine, P. Sequential Selective Extraction Procedures for the Study of Heavy Metals in Soils, Sediments, and Waste Materials-A Critical Review. Crit. Rev. Environ. Sci. Technol. 2010, 40, 365-399. [CrossRef]

53. Lazareva, E.; IGM SB RAS, Novosibirsk, Russia. Personal communication, 2020.

54. Rozanov, A.G. Redox system of the bottom sediments of the western Kara Sea. Geochem. Int. 2015, 53, 987-1001. [CrossRef]

55. Manning-Berg, A.R.; Kah, L.C. Proterozoic microbial mats and their constraints on environments of silicification. Geobiology 2017, 15, 469-483. [CrossRef] [PubMed]

56. Wooyong, U.; Serne, R.J.; Brown, C.F.; Rod, K.A. Uranium(VI) sorption on iron oxides in Hanford Site sediment: Application of a surface complexation model. Appl. Geochem. 2008, 23, 2649-2657. [CrossRef]

57. Fontes, J.C.; Matray, J.M. Geochemistry and origin of formation brines from the Paris Basin, France. 1. Brines associated with Triassic salts. Chem. Geol. 1993, 109, 149-175. [CrossRef]

58. Issar, A. Climate Changes during the Holocene and Their Impact on Hydrological Systems (International Hydrology Series); Cambridge University Press: Cambridge, UK, 2003. [CrossRef]

59. Hardie, L.A. Anhydrite and gypsum. In Sedimentology. Encyclopedia of Earth Science; Springer: Berlin/Heidelberg, Germany, 1978.

60. Yechieli, Y.; Wood, W.W. Hydrogeologic processes in saline systems: Playas, sabkhas, and saline lakes. Earth Sci. Rev. 2002, 58, 343-365. [CrossRef]

61. De Lange, G.J.; Krijgsman, W. Primary Messinian Salinity Crisis shallow gypsum vs. deep dolomite formation: A unifying biogeochemical mechanism. Mar. Geol. 2010, 275, 273-277. [CrossRef]

62. Komlev, A.E. Anionic composition of groundwaters of Altai Krai. Izv. Altai Univ. 2010, 3-2, 99-103. (In Russian)

63. Paramonov, E.; Rybkina, I.; Gubarev, M. Agrarian and Forest Landscapes in Steppe: Prevention of Soil Deflation during Climate Warming. Eur. Geogr. Stud. 2019, 6, 39-49. [CrossRef]

Publisher's Note: MDPI stays neutral with regard to jurisdictional claims in published maps and institutional affiliations.

(C) 2020 by the authors. Licensee MDPI, Basel, Switzerland. This article is an open access article distributed under the terms and conditions of the Creative Commons Attribution (CC BY) license (http://creativecommons.org/licenses/by/4.0/). 